\title{
Relationship between births and deaths during the Covid-19 Pandemic in Brazil
}

\author{
Relação entre nascimentos e mortes durante a Pandemia da Covid-19 no Brasil \\ Relación entre nacimientos y muertes durante la pandemia Covid-19 en Brasil
}

Received: 01/04/2022 | Reviewed: 01/09/2022 |Accept: 01/12/2022| Published: 01/14/2022

\author{
Mario Cezar Saffi Junior \\ ORCID: https://orcid.org/0000-0002-4703-641X \\ Universidade Estadual de Ponta Grossa, Brazil \\ Centro Universitário de Maringá, Brazil \\ mariosaffi@gmail.com \\ Luiz Antonio Favero Filho \\ ORCID: https://orcid.org/0000-0002-8884-9804 \\ Universidade Federal do Espirito Santo, Brazil \\ luizfavero@gmail.com \\ Giovani Marino Favero \\ ORCID: https://orcid.org/0000-0002-1946-3262 \\ Universidade Estadual de Ponta Grossa, Brazil \\ E-mail: gmfavero@uepg.br
}

\begin{abstract}
The Covid-19 pandemic started in December 2019 in China and in March of the same year in Brazil, impacted the healthcare structure which, due to its expansion in recent decades, was able to absorb a large part of the patients of this new disease. Despite the robustness of the Brazilian Unified Health System, the country was among those that had the most deaths related to the new corona virus and its associated diseases. At the same time, for the second consecutive year there was a lower number of births in the country, anticipating an assessment of expected vegetative growth for approximately ten years. In an article published in the same periodical last year, we explored the panorama of deaths and Intensive Care Units, especially children, in Brazil. We found that we could forcibly have an increase in the number of beds and with the decrease in births in the country, we can stay close to the values recommended by the Pediatrics Societies. Here we aim to maintain the pattern of analysis of the dead and the born, with a focus on those under twenty. The methodology used was a systematic review with exploration of related literature and public databases. The data suggest that Brazil is in a process of vegetative growth. This is due to a reduction in the number of births in the last two years compared to 2019 and a significant increase in deaths directly related to the new Corona virus pandemic. An important fact is that Covid-19 affects children and adolescents and that the decrease in cases is associated with intense vaccination in the country.
\end{abstract}

Keywords: Covid-19; Birth certificates; Mortality; Population growth.

\section{Resumo}

A Pandemia do Covid-19 iniciada em dezembro de 2019 na China e em Março do mesmo ano no Brasil, impactou a estrutura de saúde que, devido a sua ampliação nas últimas décadas, foi capaz de absorver boa parte dos doentes dessa nova doença. Apesar da robustez do Sistema Único de Saúde brasileiro, o país ficou entre os que mais tiveram mortes relacionadas ao novo corona vírus e suas doenças associadas. Paralelamente, pelo segundo ano consecutivo houve um menor número de nascimentos no país, antecipando uma avaliação de crescimento vegetativo esperada para aproximadamente dez anos. Em um artigo publicado nesse mesmo periódico, no ano passado, exploramos o panorama das mortes e as Unidades de Terapia Intensiva, principalmente infantis, no Brasil. Constatamos que forçadamente pudemos ter uma ampliação nos números de leitos e com a diminuição dos nascimentos no país, podemos ficar próximo aos valores recomendados pelas Sociedades de Pediatria. Aqui objetivamos manter o padrão de análise dos mortos e nascidos, dando um destaque aos menores de vinte anos. A metodologia utilizada foi uma revisão sistemática com exploração da literatura relacionada e os bancos de dados públicos. Os dados sugerem que o Brasil está em processo de crescimento vegetativo. Isso se deve a uma redução no número de nascimentos nos últimos dois anos em comparação com 2019 e a um aumento significativo nas mortes diretamente relacionadas à nova pandemia do vírus Corona. Um fato importante é que o Covid-19 atinge crianças e adolescentes e que a diminuição dos casos está associada à vacinação intensa no país.

Palavras-chave: Covid-19; Registro de nascimento; Mortalidade; Crescimento demográfico.

\section{Resumen}

La pandemia Covid-19, iniciada en diciembre de 2019 en China y en marzo del mismo año en Brasil, impactó la estructura sanitaria que, debido a su expansión en las últimas décadas, logró absorber a gran parte de los pacientes de 
esta nueva enfermedad. A pesar de la solidez del Sistema Único de Salud de Brasil, el país fue uno de los que tuvo más muertes relacionadas con el nuevo virus corona y sus enfermedades asociadas. Al mismo tiempo, por segundo año consecutivo hubo un menor número de nacimientos en el país, anticipando una evaluación de crecimiento vegetativo esperada para aproximadamente diez años. En un artículo publicado en la misma revista el año pasado, exploramos el panorama de muertes y Unidades de Cuidados Intensivos, especialmente niños, en Brasil. Descubrimos que podríamos tener por la fuerza un aumento en el número de camas y con la disminución de los nacimientos en el país, podemos mantenernos cerca de los valores recomendados por las Sociedades de Pediatría. Aquí, nuestro objetivo es mantener el patrón de análisis de los muertos y nacidos, con un enfoque en los menores de veinte años. La metodología utilizada fue una revisión sistemática con exploración de literatura relacionada y bases de datos públicas. Los datos sugieren que Brasil se encuentra en un proceso de crecimiento vegetativo. Esto se debe a una reducción en el número de nacimientos en los últimos dos años en comparación con 2019 y a un aumento significativo en las muertes directamente relacionadas con la nueva pandemia del virus Corona. Un dato importante es que el Covid-19 afecta a niños y adolescentes y que la disminución de casos se asocia con la vacunación intensa en el país.

Palabras clave: Covid-19; Certificado de nacimiento; Mortalidad; Crecimiento demográfico.

\section{Introduction}

After a decline in the number of Covid-19 cases in early 2021 (Rosemberg et al.,2021), we had the highest number of infections and deaths in the fall and winter of that year (Registro Civil, 2021). The Pandemic was declared in March 2020 and began in late 2019 in Wuhan, China (Huang et al., 2020; Zhu et al., 2020). The disease initially seen as a severe acute respiratory syndrome, hence the acronym SARS-CoV-2 (Vrancken et al., 2021; Sabino et al., 2021), showed that sequelae and secondary bacterial infections would add to the tragic end of many of those affected by the disease (Bradley et al., 2020; Oliveira et al., 2021; Moura et al, 2021).

In a paper published in the same periodical last year, we explored the panorama of deaths and Intensive Care Units, especially children, in Brazil. We found that we could forcibly have an increase in the number of beds and with the decrease in births in the country, we can stay close to the values recommended by the Pediatrics Societies (Saffi et al., 2021).

Here we aim to maintain the pattern of analysis of the dead and the born, with a focus on those under twenty. As data related to ICUs in 2021 has not yet been released, we have not addressed this issue at this time.

\section{Methodology}

The methodology used follows the pattern of systematic reviews (Aires et al., 2020), with a search for scientific papers in digital databases such as Scielo, PubMed, Medrxiv, MedLine, the Brazilian Institute of Geography and Statistics, in addition to the National Civil Registry Center (Registro Civil, 2021).

Some of the charts are automatically generated on the National Civil Registry Center website, the others were carried out in the WPS Office spreadsheet program - Spreadsheets (available at https://www.wps.com/download/).

\section{Results and Discussion}

From the first death on March 16, 2020 to December 31, 2021, 60,5105 Brazilians died of Covid-19, most in the year 2021 , totaling 404,815 in that period. In $2021,1,721,579$ deaths were registered, $23.5 \%$ of which were related to the new coronavirus disease. Compared to the previous year, it obtained 13.4\% (Saffi et al.2021), that is, $10 \%$ less. The curve of deaths since the beginning of the pandemic is shown in Figure 1A, the evolution of deaths in 2021 is shown in Figure 1B shows the evolution of deaths in that period (Civil Registry, 2021). 
Figure 1: A) Curve of deaths during the beginning to the end of 2021 of the Covid-19 Pandemic; B) Assessment of deaths during 2021 related to the new coronavirus.

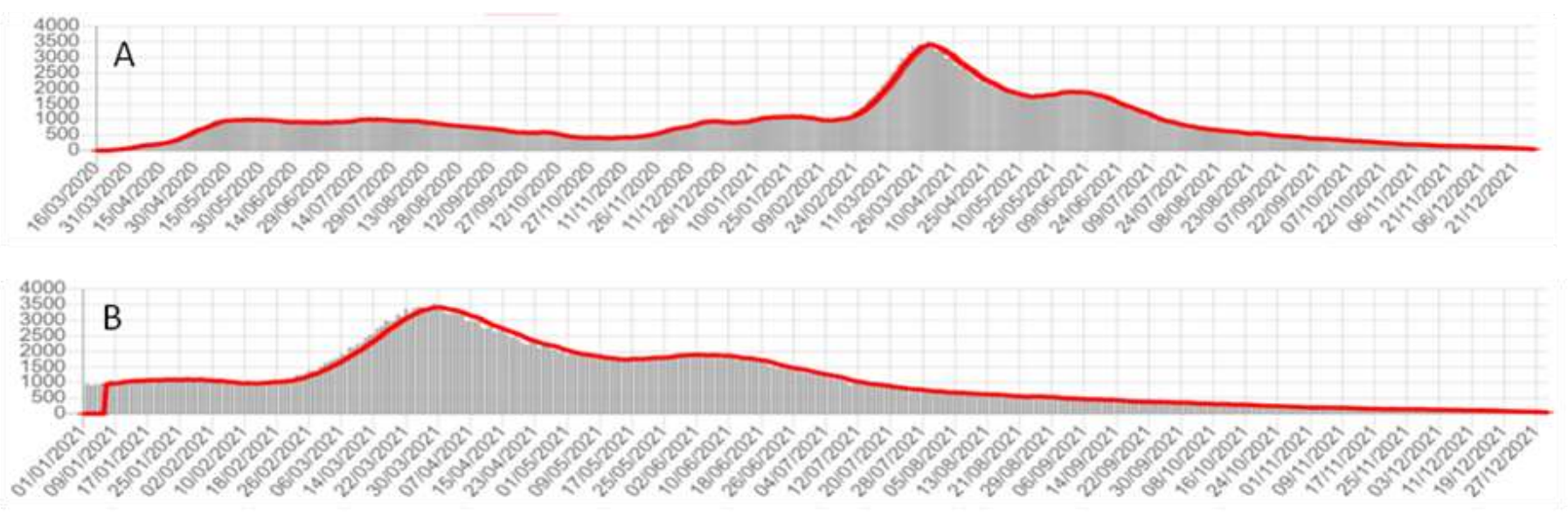

Adapted from Central de Informaçöes do Registro Civil - CRC Nacional

Source: Authors.

The results show that unlike 2020, where the peak of the daily average of deaths was in the winter period, in 2021 the peak of the curve was on March 30th, followed by high daily death rates in April and May. The decline is associated with the activity and expansion of the vaccinated population, reaching double digits by the end of the year.

The pattern of deaths remained stable throughout the pandemic, with the largest victims being elderly over 70 years old, although in 2021 the largest range was between 60 and 70 years old (Macedo et al.,2021; Mercês et al., 2020; Paixão et al., 2021; Sousa et al., 2021). The male gender, regardless of age group, was the most affected by death by Covid-19. These data are shown in Figure 2.

As demonstrated in a previous study, the life expectancy of world populations, and in particular that of Brazil, has dropped, and the real predictive value must be demonstrated in the next sense. In 2019 there were 1,262,200, in 2020 $1,450,994$ and in 2021 1,721,579. If we take into account that the total number of deaths from Covid-19 until December 31 , 2021 was 605,105 people, it is clear compared to the beginning of the pandemic that the difference was undoubtedly the pandemic.

In our previous study (Saffi et al.,2021), we showed that there was a decrease of approximately 100,000 fewer births in 2020 when compared to 2019. In 2021, 2,612,799 were registered, ten thousand more than 2020 but still 90,000 fewer than 2019. Thus, we can say that at least second year in a row, the Brazilian population grew less than in past decades.

Figure 3 shows the evolution of the number of deaths in the last 3 years and the decrease in the speed of births over the same period. 
Figure 2: Observational assessment of the age profile of deaths by Covid-19. A) The entire period from March 2020 to December 31, 2021; b) Year 2021.
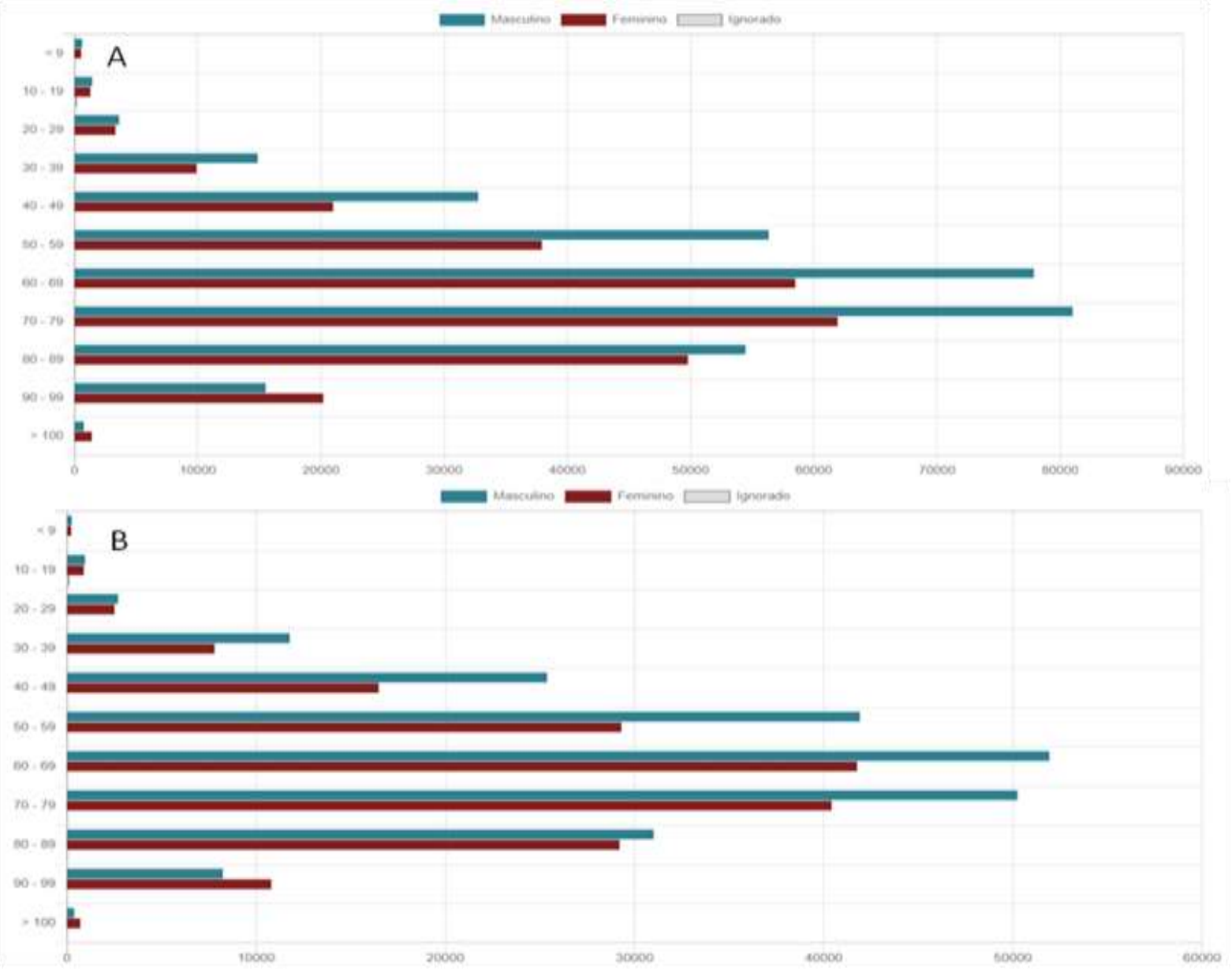

Adapted from Central de Informaçóes do Registro Civil - CRC Nacional

Source: Authors.

Figure 3: Demonstration of the decrease in births and the increase in the number of deaths in Brazil in the last 3 years.

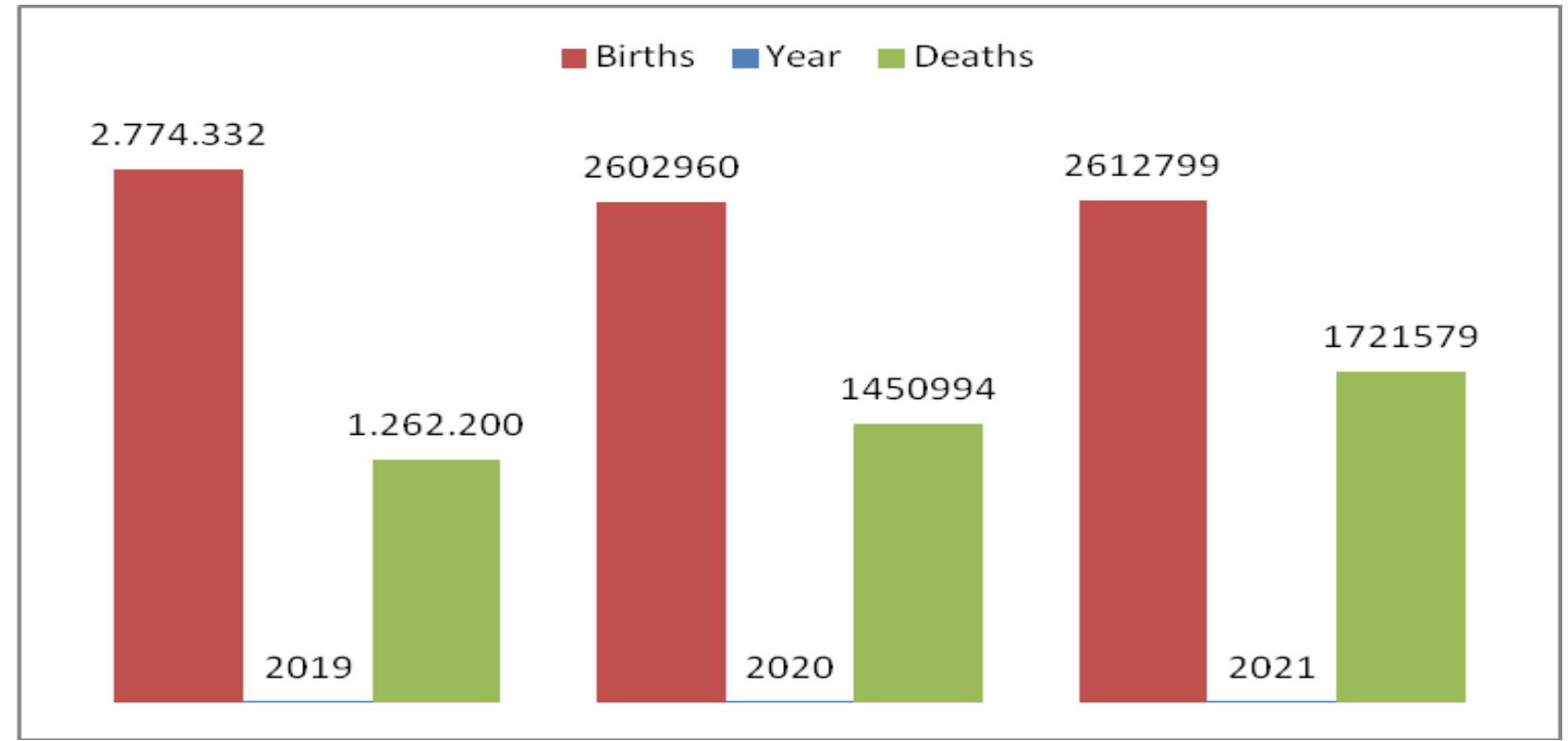

Source: Authors. 
The pandemic pattern is very similar across the world. In Brazil, individuals under 20 years of age were the least affected. In total 1,155 children under the age of nine died, 613 boys and 542 girls. Between the ages of 10 and 19 we had 1425 men and 1273 girls who lost their lives to Covid-19. Figure 4 shows the number of deaths in the country, deaths related to Covid-19 and these two age groups.

Figure 4: Number of deaths in the last 3 years in Brazil. Covid-19 related deaths generally and in two age groups, nine years of age or younger and 10-19 years of age.

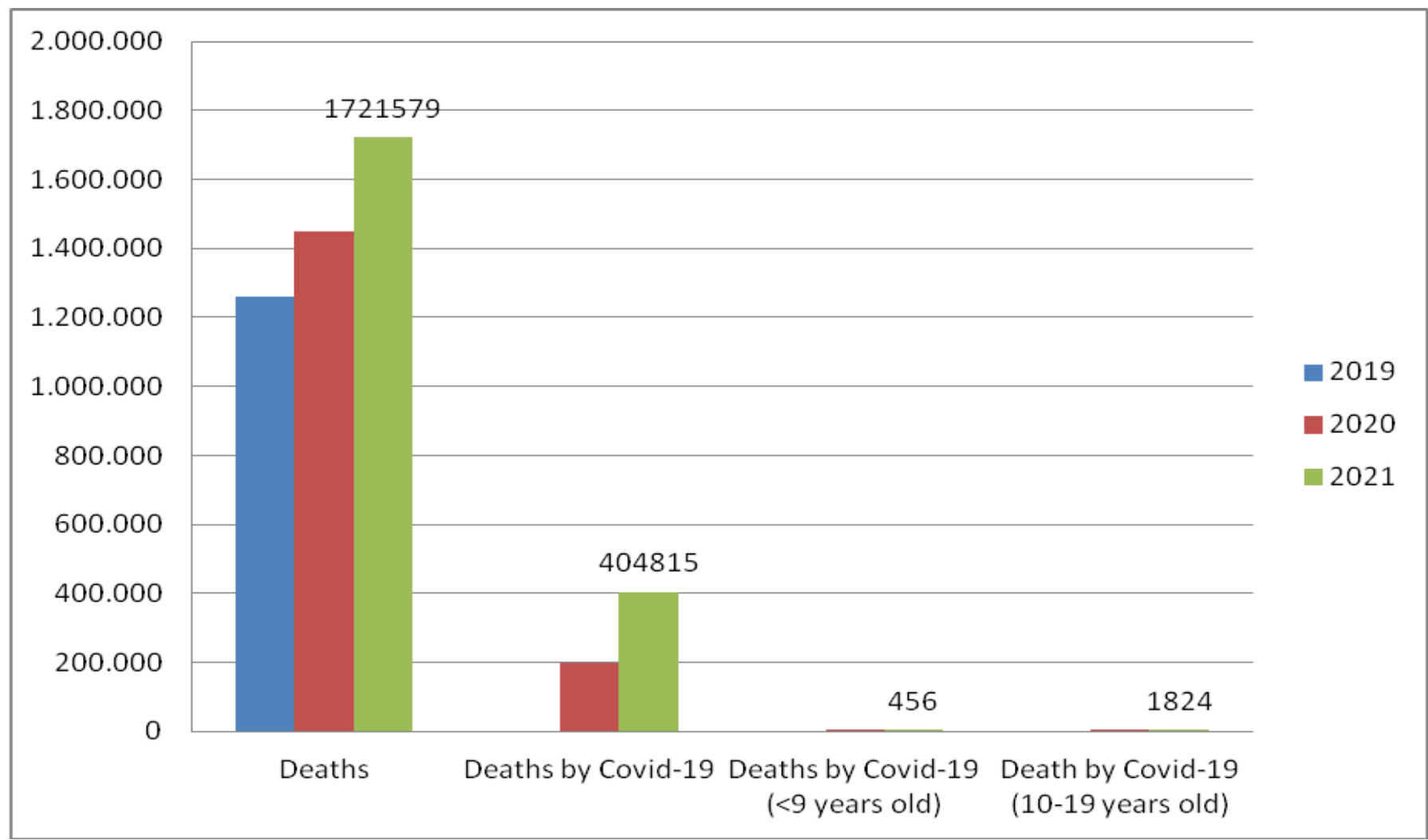

Source: Authors.

\section{Conclusion}

The data suggest that Brazil is in a process of vegetative growth. This is due to a decrease in births in the last two years compared to 2019 and a significant increase in deaths directly related to the new Corona virus pandemic. An important fact is that Covid-19 affects little children and adolescents and that the decrease in cases is associated with intense vaccination in the country.

This work is a continuation of a previous article published in the same magazine last year. Thus, we were able to observe the evolution and retraction of the pandemic.

Historically, viral respiratory pandemics have a pattern of four to five years. Thus, we will monitor the data until the World Health Organization declares the Corona Virus Pandemic as finalized and, thus, make a compilation of all the findings from the initial period, with a focus on Brazil.

\section{References}

Aires, C. F. \& Pimenta, H. C. D. (2020). Environmental practices in university chemical laboratories: a systematic literature review. Research, Society and Development. 9(8), e378985490. https://doi.org/10.33448/rsd-v9i8.5490. 
Bradley, J., Langford, M. S., Sumit Raybardhan, V. L., Duncan Westwood, D. R. MacFadden, J-P. R., Soucy, N. D. (2020) Bacterial co-infection and secondary infection in patients with COVID-19: a living rapid review and meta-analysis, Clinical Microbiology and Infection, 26(12), 1622-1629, https://doi.org/10.1016/j.cmi.2020.07.016.

Macedo, G. B., Macedo, J. B., Garcia, L. A., Ferreira, A. F., Macedo, D. B., Bortoleto, C. S., Pavinatto, A. \& Tim, C. R. (2021). Epidemiological and spatial analysis of COVID-19 in the State of Piauí. Research, Society and Development. 10, 5 (May 2021), e55010515313. https://doi.org/10.33448/rsd-v10i5.15313.

Mercês, S. O. das, Lima, F. L. O. \& Vasconcellos Neto, J. R. T. (2020). Association of COVID-19 with: age and medical comorbidities. Research, Society and Development. 9(10), e1299108285. https://doi.org/10.33448/rsd-v9i10.8285.

Moura, E. L. de, Ferreira, J. M., Santos, A. C. M., Silva, D. M., Silva, M. L. F., Silva, G. K. M. de O., Silva, P. H. N., Santos, J. A., Barbosa Junior, M. A. da S., Lira Neto, A. B., Silva, A. C. P., Fraga, C. A. de C., Farias, K. F., \& Figueiredo, E. V. M. de S. (2021). Comorbidities increase the risk of severity and mortality in COVID-19 patients: a systematic review and meta-analysis. Research, Society and Development. 10(2), e50010212533. https://doi.org/10.33448/rsd-v10i2.12533.

Oliveira, M. I. da S., Brandão, C. B. F., Costa, K. V. da, Silva, J. P. dos S., Fernandes, V. M. de S., Brito, G.E.G. de., Elihimas Júnior, U. F. \& França, E. E. T. (2021). What are the pulmonary ventilation strategies in the acute respiratory distress syndrome caused by COVID-19? A review study. Research, Society and Development. 10(1), e51110112037. https://doi.org/10.33448/rsd-v10i1.12037.

Paixão, C. N., Moreira, J. E. de M., Moreira, P. M. B., Braga Junior, A. C. R. \& Amorim, A. T. (2021). Epidemiological profile of deaths by Covid-19 in Vitória da Conquista, Bahia, Brazil. Research, Society and Development. 10(16), e454101623832. https://doi.org/10.33448/rsd-v10i16.23832. Registro Civil. (2021). https://registrocivil.org.br/

Rosenberg, E. S., Holtgrave, D. R., Dorabawila, V. et al. (2021). New COVID-19 Cases and Hospitalizations Among Adults, by Vaccination Status - New York, MMWR Morb Mortal Wkly Rep. 70(37):1306-11. 10.15585/mmwr.mm7037a7"Sabino E C. (2021). Resurgence of COVID-19 in Manaus, Brazil, despite high seroprevalence. The Lancet. 397(10273):452-455.

Saffi Jr., M. C., Favero Filho, L. A. \& Favero, G. M. (2021). Observational analysis of Birth, Neonatal Intensive Care Unit and Deaths in Brazil during the first year of the New Corona Virus Pandemic. Research, Society and Development. 10(10), e81101018578. 10.33448/rsd-v10i10.18578. https://rsdjournal.org/index.php/rsd/article/view/18578.

Sousa, N. G., Cardoso, A. de O., Cardoso, R. F. \& Utsumi, A. G. (2020). Analysis of the transmission dynamics of COVID-19 in Minas Gerais: Modeling and Simulation. Research, Society and Development. 9(8), e812986611. https://doi.org/10.33448/rsd-v9i8.6611.

Vrancken B. (2021). Phylogenetic analyses of SARS-CoV-2 B. 1.1. 7 lineage suggest a single origin followed by multiple exportation events versus convergent evolution. bioRxiv.

World Health Organization (2021). WHO Coronavirus (COVID-19) Dashboard. https://covid19.who.int/ 